\title{
Faunal Diversity of the Little Rann of Kachchh (LRK), Gujarat, India
}

\author{
Jigar D. Joshi*1, Ketan Tatu ${ }^{2}$, Darpak Joshi ${ }^{3}$ and R. D. Kamboj ${ }^{4}$ \\ ${ }^{1,2,3,4}$ Gujarat Ecological Education and Research (GEER) Foundation, Indroda Nature Park, Gandhinagar, Gujarat, India \\ *Corresponding Author: jigarjoshi4mylife@gmail.com, Tel +919998193508
}

Available online at: www.isroset.org

Received: 06/Oct/2018, Accepted: 22/Oct/2018, Online: 31/Oct/2018

\begin{abstract}
A study on vertebrate faunal diversity (i.e., diversity of mammals, birds, reptiles and amphibians) of the Little Rann of Kachchh (LRK), Gujarat, India was conducted from October 2015 to March 2017. The Little Rann of Kachchh (LRK) represents a unique ecosystem with combination of saline desert and a vast seasonal wetland. A large portion of the LRK is under legal protection as the Wild Ass Sanctuary (WAS). Islands (locally called bet) are the unique sub ecosystems in the ecosystem of Little Rann of Kachchh. There are around 74 bets and 'dhasi' in the LRK. Owing to their relatively better vegetation status, bet's also support relatively rich fauna. Western, Eastern, Southern and Northern fringe areas of The Rann also have good habitat diversity and hence, they too have good fauna. A total of 260 species of wild vertebrates (i.e., mammals, birds, reptiles and amphibians) were recorded during the present study. They included 26 species of mammals, 210 species of birds, 20 species of reptiles and 4 species of amphibians.
\end{abstract}

Key words: Amphibians, Birds, Faunal Diversity, Fringes, Herpetofauna, Islands (Bet's), Little Rann of Kachchh (LRK), Mammals, Reptiles.

\section{INTRODUCTION}

The Little Rann of Kachchh (LRK) is a salt-impregnated wilderness area that is recognized as 'a space without a counterpart on the globe' [1] [2]. It is a unique landscape with thousands of square kilometres area. It is surrounded by Kachchh, Banaskantha, Patan, Surendranagar and Morbi districts of Gujarat State, India. The Little Rann of Kachchh, having triangular configuration and 5,180 sq. $\mathrm{km}$ area is located between $23^{\circ} 10^{\prime} \mathrm{N}$ to $23^{\circ} 45^{\prime} \mathrm{N}$ and $70^{\circ} 45^{\prime} \mathrm{E}$ to $71^{\circ} 45^{\prime}$ E with its south-western apex connected with the Gulf of Kachchh [3]. The LRK is a remarkably flat land [4] [5]. It is also a seasonally flooded wetland ecosystems [6] [7] [8]. The western most part of the Rann acts as a mouth along the Gulf of Kachchh (GoK), through which sea water is drained towards in the inland areas of this landscape [9]. As per the past study in 1990s, this unique landscape is inhabited by a large number of faunal species including 19 species of mammals, 178 species of birds and 33 species of herpetofauna [4] [5]. The existing faunal species inhabit various ecosystems and micro-ecosystems in the LRK landscape for resting, roosting, foraging and breeding life requisites [7]. Islands (i.e., bet's) are the unique ecosystems in the LRK landscape that are known to support a variety of wild animal species including the flagship species of LRK, viz. Indian Wild Ass (Equus hemionus khur) [10]. There are around 74 Islands (bet's) in the LRK [4] [5] and larger ones among them can be considered to be the "oases" amidst the vast saline flats of the Rann owing to relatively better vegetation status (sometimes with freshwater availability). Due to relatively better vegetation status, bets are capable of supporting relatively rich fauna [7]. However, fringe areas (i.e., Western, Eastern, Southern and Northern) of this landscape are very close to the human habitation owing to which these play very important role as having a good number of habitats and vegetation status. Fringes of the LRK support wide range of the faunal diversity due to presence of remarkable agriculture cropland area and water body with human settlement that provide suitable corridor for biodiversity. This juxtaposed combination of habitats support relatively higher faunal profile. The present study focused on faunal diversity of the Little Rann of Kachchh (LRK), Gujarat. India.

\section{STUDY AREA}

The Little Rann of Kachchh is located between $23^{\circ} 10^{\prime} \mathrm{N}$ to $23^{\circ} 45^{\prime} \mathrm{N}$ Latitudes and $70^{\circ} 45^{\prime} \mathrm{E}$ to $71^{\circ} 45^{\prime} \mathrm{E}$ Longitudes [5]. It is located on the western part of the Gujarat State. The entire area covered under the Wild Ass Sanctuary (3,569 sq. km) [5] is spread over Surendranagar and Morbi Districts of Saurashtra region, Patan, Banaskantha and Mahesana districts of North Gujarat region and Kachchh district of Kachchh region. 
The Little Rann of Kachchh is triangular shaped landscape which located partly in Kachchh biotic province (3A) of Indian Desert Bio-geographic Zone (3) and partly in Gujarat-Rajwada biotic province (4B) of the Semi-Arid Bio-geographic Zone (4). One of the most striking features of the LRK is the salt-encrusted mud-flats interspersed with Bet's (Islands).

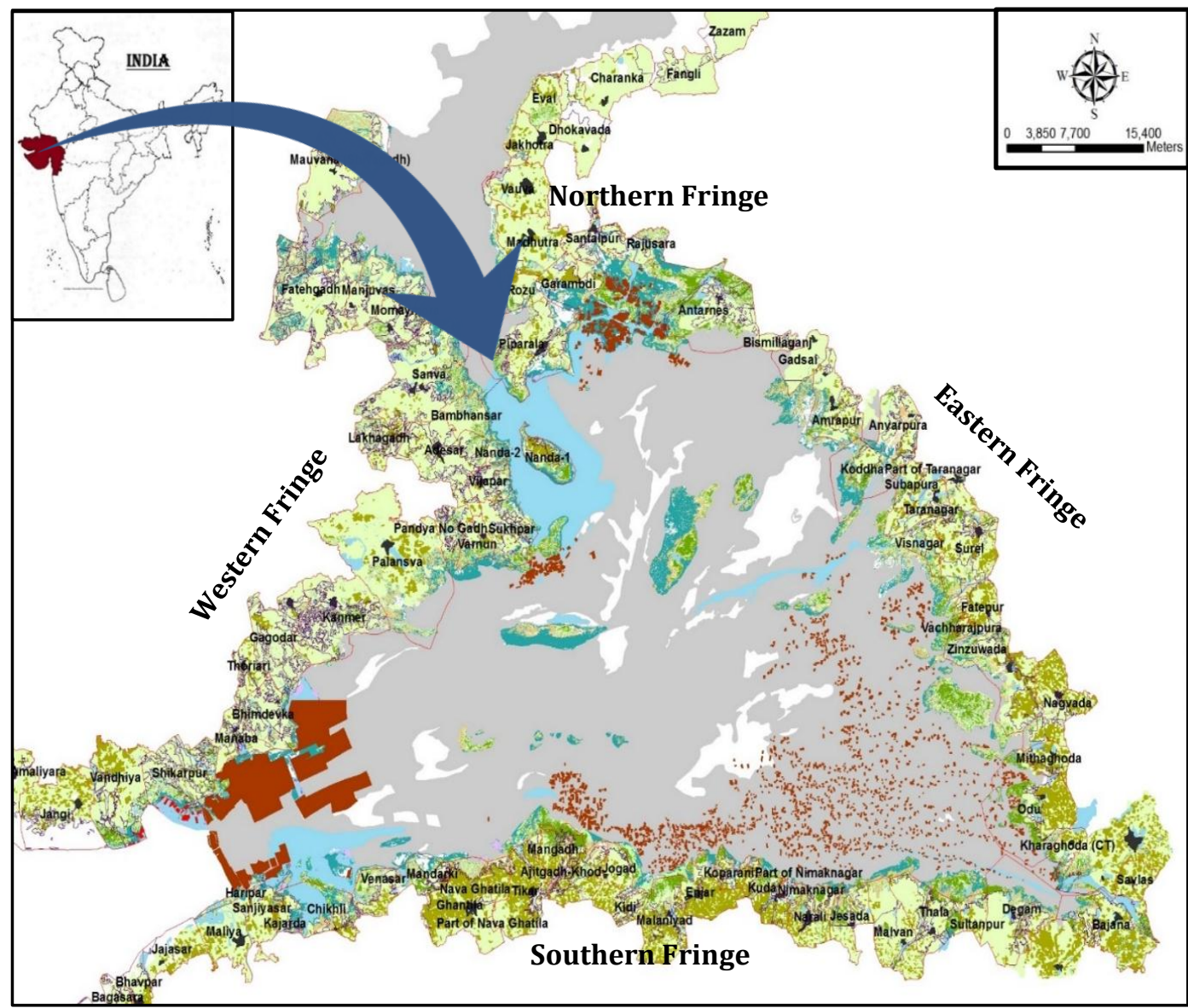

Figure 1: Study Area - Little Rann of Kachchh (LRK) landscape

\section{METHODOLOGY}

The entire task of building faunal inventory and recording important observations and deriving patterns/trends of faunal diversity was largely based on conducting transect-based survey [11] [12]. The survey recorded the faunal inventory through 63 transects (Fig. 2) in the Rann in different season. These transects were laid in three types as follows:

(I) Fringe Transects $(\mathrm{n}=23$; total length $71.2 \mathrm{Km})$

(II) Bet Transects $(\mathrm{n}=32$; total length $81.8 \mathrm{Km})$

(III) Transitional Transects (Fringe-to-bet) $(\mathrm{n}=8$; total length $98 \mathrm{Km})$

The total length of all transects conducted for recording faunal observation was $251 \mathrm{~km}$ and these transects were conducted seasonally, covering post-monsoon, summer and winter season. In each season, each transect was conducted once in the morning (i.e., between 0630 hrs. and 1000 hrs.) and once in the evening (i.e., between 1600 hrs. and $1830 \mathrm{hrs}$.).

Apart from the transect-based survey, the area was also intensively explored opportunistically during day and night for recording any mammalian and herpetofaunal species outside/beyond transect. For identification of species as well as their indirect sign, well known and widely used field guides and published articles were used. For birds [13] [14] [15], for Mammals, [16] [17] [18] and for Herpetofauna (i.e., Reptile and Amphibians collectively) [19] [20] [21] [22] were used. 
Birds and mammals were observed and recorded using a pair of 10x50 binoculars, a spotting scope (16-48X/20-60 X), a DSLR camera, GPS unit and predesigned datasheets. Camera traps were also used for detecting the presence of secretive and/or nocturnal animals (mainly mammals). The collected data were further analysed for various findings.

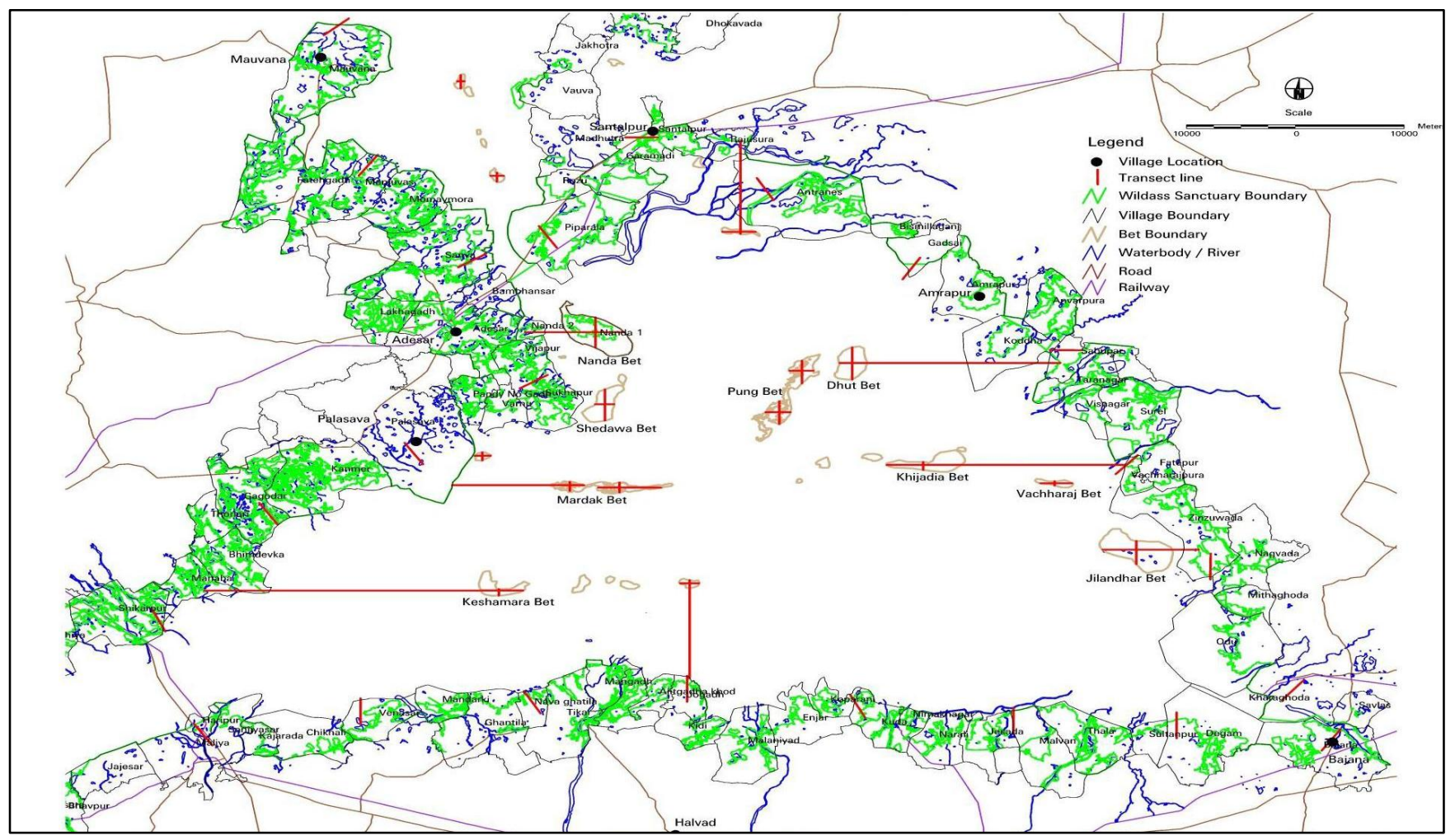

Figure 2: Distributions of transects in Little Rann of Kachchh (LRK) landscape.

\section{RESULTS AND DISCUSSIONS}

During the present study, a total of 260 faunal species were recorded. Out of these, 26 species of mammals belonging to 17 families, 210 species of birds belonging to 50 families, 20 species of reptiles belonging to 13 families and 4 species of amphibians belonging to 2 families were recorded in the LRK landscape.

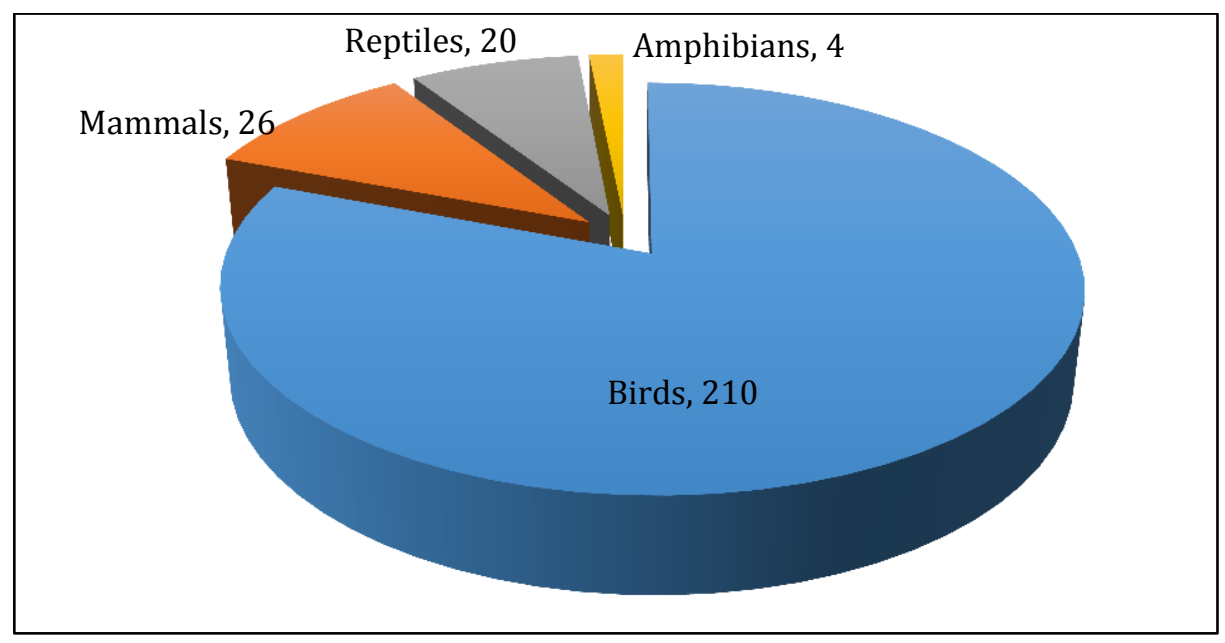

Figure 3: Faunal species richness of the Little Rann of Kachchh (LRK) landscape 


\section{Fringe-wise faunal species composition}

Amongst all the four fringes (i.e., Western, Eastern, Southern and Northern) surveyed through transect-work, the highest faunal species richness $(n=238)$ was recorded on the Western fringe followed by Eastern fringe $(n=219)$. Nonetheless, the southern fringes also have remarkable faunal species $(n=207)$. The lowest faunal species richness $(n=26)$ were recorded from the Northern fringe area as it comprises of very small area as compared to other fringes.

Western fringe: The area of the Western fringe is the largest compared amongst all fringes of the LRK landscape. Which covered 1, 21,384 ha. Out of the total fringe area, maximum area is occupied by agricultural fallow land (i.e. 55,517.7 ha) followed by mudflat (i.e. 22,104 ha) and sparse tree cover (i.e. 12,195 ha). Smaller areas were covered by village settlement (i.e. 894.7 ha), aquatic vegetation (i.e. 748.0 ha) and salt encrusted area (i.e. 624.0 ha). Investigation from the faunal diversity point of view showed presence of a total of 238 species of wild fauna which included, 26 mammalian species, 193 species of birds and 19 species of herpetofauna. The highest species richness in these fringes indicate that the presence of vast agriculture fallow land, sparse tree cover and few village settlement areas provide suitable habitat or corridor for wildlife.

Eastern Fringe: The Eastern fringe is spread over an area of 98,891 ha. Out of this area, the maximum area is occupied by agriculture fallow land (i.e. 30,084.5 ha) followed by mudflat (i.e. 22,154.8 ha) and agriculture cropland (i.e. 13,331.8 ha). A few areas were under open land area (i.e. 906.4 ha), village settlement area (i.e. 867.9 ha), salt-encrusted area (i.e. 777.0 ha), aquatic vegetation (i.e. $390.1 \mathrm{ha}$ ) and 347.0 ha area was covered by dhasi. Investigation from the faunal diversity point of view showed presence of 219 species of wild vertebrate fauna. Which includes, 25 species of mammals, 182 species of birds and 12 species of herpetofauna. The second largest fringe of the LRK supports wide range of the biodiversity due to the large area covered by this fringe and presence of remarkable agriculture cropland area, water body with human settlement that provide suitable corridor for biodiversity.

Southern Fringe: The Southern fringe is smaller than Eastern and Western fringe but, larger than Northern fringe and occupies 93,397.2 ha area. Out of this area, the maximum area is occupied by agriculture fallow land (i.e. 30,098.1 ha) followed by mudflat (i.e. 17,969.4 ha) and agriculture cropland (i.e. 17,482.5 ha) whereas smaller areas were covered by salt affected (i.e. 795.3 ha), village settlement area (i.e. 737.7 ha), aquatic vegetation (i.e. 720.3 ha), open land area (i.e. 532.5 ha), salt encrusted (i.e. 499.9 ha) and very small area was covered by bet/dhasi (i.e. 53.4 ha). From faunal diversity point of view, 25 species of mammals, 172 species of birds and 10 species of herpetofauna have been recorded in this segment due to the availability of agriculture fallow land, mudflat area and agriculture cropland, which might provide food and water easily.

Northern Fringe: The area of this fringe is very small (21,650 ha) as compared to the other fringes of the LRK also the maximum area of this fringe is occupied by agriculture fallow land (i.e. 11,429.6 ha). Investigation from the faunal diversity point of view the fringe showed presence of only 26 species of wild fauna. Comprising of, 5 species of mammals, 20 species of birds and 1 species of herpetofauna.

\section{Islands (bet's) wise faunal species composition (i.e., Top ten largest Islands)}

The present study has shown that the islands (bet's) having large size (i.e., top ten larger bet's) possess high faunal species richness but, habitat diversity of a bet also contributes in shaping the faunal species richness of the bet. The top ten larger bet's were Pung bet (4592.6 ha), Jilandhar bet (2897.1 ha), Mardak bet (2653.9 ha), Nanda bet (2032.3 ha), Shedwa bet (978.7 ha), Dhut bet (824.7 ha), Keshmara bet (748.4 ha), Gon bet (500.3 ha), Vachchhraj Solanki bet (209.1 ha), and Khijadiya bet (117.5 ha) in the LRK. Among these bet's, the maximum faunal species richness $(\mathrm{n}=151)$ was recorded from Nanda bet and lowest faunal species richness $(\mathrm{n}=8)$ was recorded from Khijadiya bet.

Table 1: Islands (bet's) wise faunal species richness

\begin{tabular}{|c|c|c|c|c|c|c|c|}
\hline \multirow{2}{*}{ SN } & \multirow{2}{*}{ Bet's Name } & \multirow{2}{*}{$\begin{array}{c}\text { Area in } \\
\text { (ha) }\end{array}$} & \multirow{2}{*}{$\begin{array}{l}\text { No. of } \\
\text { Habitats }\end{array}$} & \multicolumn{3}{|c|}{ Number of Species } & \multirow{2}{*}{$\begin{array}{c}\text { Total No. o } \\
\text { Species }\end{array}$} \\
\hline & & & & Mammals & Birds & Herpetofauna & \\
\hline 1 & Nanda & 2032 & 13 & 22 & 117 & 12 & 151 \\
\hline 2 & Mardak & 2653 & 10 & 17 & 67 & 7 & 91 \\
\hline 3 & Vachchhraj Solanki & 209 & 5 & 13 & 52 & 2 & 67 \\
\hline
\end{tabular}




\begin{tabular}{|r|l|c|c|c|c|c|c|}
4 & Jilandhar & 2897 & 10 & 10 & 52 & 4 & 66 \\
\hline 5 & Shedwa & 978 & 9 & 11 & 23 & 2 & 36 \\
\hline 6 & Pung & 4592 & 9 & 10 & 12 & 2 & 24 \\
\hline 7 & Gon & 500 & 10 & 8 & 9 & 4 & 21 \\
\hline 8 & Dhut & 824 & 8 & 7 & 6 & 1 & 14 \\
\hline 9 & Keshmara & 748 & 10 & 5 & 7 & 1 & 13 \\
\hline 10 & Khijadiya & 117 & 4 & 3 & 4 & 1 & 08 \\
\hline
\end{tabular}

Nanda bet: Among all the major bets in the LRK, this bet located near Adesar on the Western Fringe, recorded the richest faunal diversity $(\mathrm{n}=151)$. This is a large bet spread over $2032 \mathrm{ha}$ area and also the one with the highest habitat diversity (i.e., 13 habitats). Nanda bet is the only bet in the LRK that has a village settlement and agriculture area. Due to large area and good habitat diversity, it supports a total of 151 species of fauna (i.e. 58\% of all the faunal species recorded for the LRK). Which includes, 22species of mammals, 117 species of birds and 12 species of herpetofauna.

Mardak bet: This is another larger bet (area 2654 ha) having the second-highest habitat diversity (i.e. total 10 habitats) that might have led to high species richness $(\mathrm{n}=91)$. Of the total, 17 species of mammals, 67 species of birds and 7 species of herpetofauna were recorded from this bet.

Jilandhar bet: This bet that falls adjacent to the Eastern fringe of the LRK, is the second largest bet of the LRK (The largest being Pung bet). The predominant habitat on this bet is tree cover (sparse- 1038.2 ha, dense- 899 ha). This might have led to avian species richness in this bet as 52 species of birds, 10 species of mammals and 4 species of herpetofauna were recorded.

Pung bet: Pung bet is the largest bet (i.e., area of 4592 ha) is located towards the Eastern fringe of the LRK. Overall habitat diversity on this bet is low (i.e., 9 habitats). This bet also experiences high human disturbance due to livestock grazing and vehicles passing through adjacent area and all these factors might have led to low species richness $(n=24)$ despite the largest area under this bet. The recorded faunal species incudes, 10 species of mammals, 12 species of birds and 2 species of herpetofauna in this bet.

Shedwa bet: The bet that falls in to Western fringe of the LRK. It is spread over in 978.7 ha. Overall habitat diversity (i.e., 9 habitats) on this bet is low. This bet experiences high human disturbance due to livestock grazing and it's very near to village boundary of shanva village in the western fringe. Increasing salt manufacturing activity and vehicle passing also create major problems. All these factors might have led to low species richness $(n=36)$. The fauna includes, 23 species of birds, 11 species of mammals and only 2 species of herpetofauna.

Dhut bet: Dhut bet is located on the north east of Pung bet on the eastern fringe. The bet spread over 824.7 ha. Overall habitat diversity (i.e., 8 habitats) on this bet is low. The predominant habitat on this bet is mudflat ( 244.9 ha) and tree cover (sparse197.4 ha, dense-183.5 ha). Due to due to livestock grazing and vehicles passing through adjacent area and all these factors might have led to very low species richness $(n=14)$. The faunal species includes, 6 species of birds, 7 species of mammals and only one species of Herpetofauna.

Keshmara bet: This bet located towards the western fringe and is comparatively far from the Rann boundary. Thus, possibility of grazing pressure of livestock on this bet might be lower than the other bets. This bet is spread over an area of 748.4 ha. Overall habitat diversity is relatively high on this bet (i.e., 9 habitats). Very less species richness $(n=13)$ which includes 5 species of Mammals, 7 species of birds and only one species of herpetofauna were recorded from this bet. The less species richness may be due to low accessibility as the Rann gets dried by end of the November or mid-December, except for lowlaying parts surrounding this bet. Which has presence of excessive mud.

Gon bet: This bet is located near the boundary of Palasava and Gagodar villages which are located on the Western fringe of LRK. The bet covers an area of 500.3 ha. Overall rich habitat diversity (i.e., 10 habitats). The bet showed low species richness $(n=21)$ which includes, 8 species of mammals, 9 species of birds and 4 species of herpetofauna though habitat diversity was rich (i.e., 10 habitats). The low species richness might be due to heavy human interference activities (i.e., livestock grazing, tree cutting, Charcoal making and other vehicular trafficking) on this bet.

Vachchhraj Solanki bet: The bet has one of the famous temple known as "Vachhra Dada Temple". It falls on the Eastern fringe of the LRK. The bet is spread over an area of 209.1 ha. The bet experiences significant grazing pressure due to presence of over 2500 cows (of a "Gaushala" associated with temple). The bet also experienced high vehicular traffic. Despite all, the bet support relatively good numbers of faunal diversity $(n=67)$ which includes 13 species of mammals, 52 species of birds and 2 species of herpetofauna. The relatively good species richness might be due to availability of combination of habitats like dense tree/scrub, mudflats and water inundation. 
Khijadiya bet: One of the smallest bet in the LRK, located on the west of Vachchhraj Solanki bet and falls on the Eastern fringe. The terrain of the bet was undulating with almost 5 to 6 feet high muddy mounds. The predominant habitat on this bet is mudflat and sparse growth of herbaceous vegetation. Due to high vehicular traffic and livestock grazing, very less number of faunal species $(\mathrm{n}=8)$ which includes, 4 species of birds and 1 species of herpetofauna were recorded.

\section{CONCLUSIONS}

The Present study revealed that the presence of 260 vertebrate faunal species were recorded from the Little Rann of Kachchh (LRK). That include, 26 species of mammals, 210 species of birds, 20 species of reptiles and 4 species of amphibians. Amongst all the four fringes, maximum faunal species $(\mathrm{n}=238)$ were recorded from Western fringe and the lowest species richness $(\mathrm{n}=26)$ was recorded from Northern fringe area of the LRK Landscape. Amongst top ten larger islands (bet's) of the LRK, the highest faunal species richness $(n=151)$ was recorded from Nanda bet and the lowest faunal species richness $(n=8)$ was recorded from Khijadiya bet. The recorded faunal species are distributed throughout the Little Rann of Kachchh (LRK) landscape.

\section{RECOMMENDATIONS}

The present study has shown that there has been any drastic reduction in species richness of fauna in LRK in the current timeframe in comparison to the species richness recorded in the past studies during late 1990s. The might be the result of good management practices planned and implemented by the Wild Ass Sanctuary (WAS) authorities (i.e., GFDs). So, it is recommended that efficient and effective PA management activities should continue in the Little Rann of Kachchh (LRK) landscape.

\section{ACKNOWLEDGEMENTS}

The authors extend thanks to The World Bank, The Ministry of Environment, Forests and Climate Change, Government of India, Forest and Environment Department, Government of Gujarat and BCRLIP society for financially supporting the Conservation Mapping of Little Rann of Kachchh Landscape-Biodiversity Conservation and Rural Livelihood Improvement (CMLRK-BCRLIP) Project. We also express our deep gratitude towards the officials \& field staff of Wild Ass Sanctuary, Dhrangadhra wildlife division and North Gujarat Wildlife Circle (Dhrangadhra range, Bajana range and Adesar range) for providing necessary logistics support during field visits. Thanks are also due to the Manager Dr. Sweta Rajpurohit for her help received in management issues during the tenure of project. Special thanks to Mr. Rakesh Patel and Mr. Harshad Patel for preparing various maps that helped in determining number of habitats and their extent of the Little Rann of Kachchh (LRK). Thanks are also due to Dr. Sandeep Munjpara, Research Associates; Mr. Ashok Suthar, JRF; Ms. Ankita Patel, Ex-JRF and Ms. Khushali Desai, Ex-JRF for their contribution in various field visits during the project tenure.

\section{REFERENCES}

[1]. Hussain, S. A. and Roy, R. “Directory of Indian Wetlands”, WWF-I, New Delhi \& AWB, Kaula Lumpur, 1993.

[2]. Merh, S. S. and Patel, P. P. "Quaternary Geology and Geomorphology of the Ranns of Kachchh”. M S University of Baroda, Vadodara, Gujarat, 1988.

[3]. Babbar, V., B. Pathak, P. Chopra, V. Kaushik, S. Tembe and J. Dave. "Current Ecological Status of Kachchh". Gujarat Ecology Commission, Vadodara, India, 1994.

[4]. Singh, H. S., B. H. Patel, R. Pravez, V. C. Soni, Nita Shah, Ketan Tatu and Dimple Patel. "Ecological Study of Wild Ass Sanctuary, Little Rann of Kachchh" (A comprehensive study on biodiversity and management issues). Published by Gujarat Ecological Education and Research (GEER) Foundation, Gandhinagar, Gujarat, 1999.

[5]. Parmar, M. J., Chaudhary, J. S., Singh, P. and Pandey, C. N. “Management Plan for Wild Ass Sanctuary”, Gujarat Forest Department, Gujarat, India, 2014.

[6]. Merh, S. S. and Malik, J. J. "Kachchh Peninsula \& Rann of Kachchh (A report of the DST Project of Neotectonic \& Paleosesmic Studies on Kach(hh)”. Department of Geology. M. S. University, Vadodara, pp-41, 1996.

[7]. Joshi Jigar D., Ketan Tatu, Darpak Joshi and R. D. Kamboj. "Comparative account of faunal diversity of four major Islands (Bet's) in the Little Rann of Kachchh (LRK), Gujarat, India". International Research Journal of Biological Sciences. Vol. 7(6), pp-9-19, 2018.

[8]. Suthar Ashok M., Ketan S. Tatu and R. D. Kamboj. "Status of Grasses and Sedges used as main natural food plants by Indian Wild Ass in the fringe area of Little Rann of Kachchh (LRK), Gujarat, India". International Research Journal of Biological Sciences. Vol. 7(5), pp-28-31, 2018.

[9]. Gupta Vishal and Ansari A. A. "Geomorphodynamics \& Morpho-Ecological Management in the Little Rann of Kachchh”. P.hD. Thesis Vadodara: The Maharaja Sayajirao University of Baroda, 2011.

[10]. Shah, N. V. "Ecology of Wild Ass (Equus hemionus Khur) in Little Rann of Kachchh". P.hD. Thesis. Vadodara: The Maharaja Sayajirao University of Baroda, 1993. 
[11]. Urfi, A. J., Monalisa Sen, Kalam, A. and Meganathan, T. “Counting birds in India: Methodologies and trends”. Current Science, vol. 89(12), 2005.

[12]. Sutherland William J. “A Handbook of Ecological Census Techniques”. Second Edition. Published by Cambridge University Press. New York, 2006.

[13]. Shah, N., Pilo, B. and Goyal, S. P. Avifauna of Wild Ass Sanctuary, Gujarat. PAVO, 33, pp-135-144, 1995.

14 Ali, S. "The Book of Indian Birds". Bombay Natural History Society, Oxford University Press, Mumbai.

15 Grimmett, R. C. Inskipp and T. Inskipp. "Birds of Indian Subcontinent-Pocket Guide”. Oxford University Press. New Delhi, 1998.

16 Menon, V. and Daniel, J. C. “A Field Guide to Indian Mammals”. Publisher-Dorling Kindersley, India, 2003.

17 Singh, H. S. "Mammals in Gujarat". Gujarat Biodiversity Board and Gujarat Forest Department, Gandhinagar, pp-299, 2013.

18 Menon, V. "Indian Mammals: A Field Guide". Hachette Book Publishing India Pvt. Ltd. 2014.

19 Daniel, J. C. "The Book of Indian reptiles". Bombay Natural History Society. Bombay, 1983.

20 Shah, N., Pilo, B. and Goyal, S. P. "Herpetofauna Diversity in Little Rann of Kachchh and Conservation needs". Zoos Print. Vol. 7 (11), pp-5, 1992.

21 Naik, Y. M. and Vinod, K. R. "Amphibian Fauna of Gujarat: An Updated Checklist with Key to the Identification of Species". Journal of Animal Morphology and Physiology. 43 (2), pp - 191-194, 1996.

22 Vyas, R. "The reptiles of Gujarat State: Updated distribution". Tiger paper 25(1) pp-8-14, 1998. 